Patricia Martínez García de Leaniz

martinezrp@unican.es

University of Cantabria

Faculty of Economics

Avenida de los Castros s/n

39005 - Santander (Cantabria, Spain)

Phone number: +0034.942.20.16.61

Ignacio Rodríguez del Bosque Rodríguez

rbosquei@unican.es

University of Cantabria

Faculty of Economics

Avenida de los Castros s/n

39005 - Santander (Cantabria, Spain)

Phone number: +0034.942.20.16.61 


\title{
SUSTAINABILITY DIMENSIONS: A SOURCE TO ENHANCE CORPORATE REPUTATION
}

\begin{abstract}
The aim of this paper is to enhance our understanding of the relationship between sustainability and corporate image and reputation according to the legitimacy theory framework since the current academic literature does not have an understanding of how sustainability and corporate image and reputation interact. Authors conducted a survey to test the hypotheses. The study was tested using data collected from a sample of 382 Spanish consumers. The proposed hypotheses were analyzed through a structural equation model showing that sustainability plays a vital role as antecedent of both corporate image and reputation. Findings suggest that the economic, social and environmental domains of sustainability present a direct and positive relationship with both corporate image and reputation.
\end{abstract}

Keywords: Sustainability, economic dimension, social dimension, environmental dimension, legitimacy theory, corporate reputation, corporate image

\section{Introduction}

Nowadays, sustainability is an emerging trend. Most academics and practitioners claim that how executives respond to the challenge of sustainability will profoundly affect the competitiveness and even the survival of organizations (Lubin and Esty, 2010). Several academics describe sustainability as the essential and most important challenge for modern marketing (Sheth et al., 2011). Despite these advances, sustainability research has not become a widely studied topic in premier marketing journals ${ }^{1}$.

Additionally, practitioners and academics have become increasingly interested in the notion of sustainability and how it relates to other concepts such as corporate image and reputation (Fombrun, 2005; Hillelbrand and Money, 2007). In part, this is due to the belief that elements of sustainability are key drivers of corporate image and reputation (Fombrun, 2005; Hillelbrand and Money, 2007; Pfau et al., 2008). Several authors highlight the relevance of both intangible assets to the overall organizational performance (Miles and Covin, 2000). Academic literature has suggested including sustainability standards as antecedents of a good image and reputation (Fombrun, 2005; 
Hillelbrand and Money, 2007). The current academic literature does not have a clear understanding of how sustainability and corporate image and reputation interact. In fact, little is known about the influence of sustainability dimensions on corporate image and reputation. Although significant efforts have been made to study the influence of corporate social responsibility (CSR) on corporate image and reputation, there is a lack of research focusing on a sustainability context. In the CSR context, Keller and Aaker (1998) demonstrate that corporate marketing activities related to concern with the environment and community involvement increase perceptions of corporate credibility. Similarly, Pfau and colleagues (2008) analyze how CSR campaigns are effective in influencing people's perceptions, in terms of corporate image, reputation and credibility. Hillenbrand and Money (2007) investigate the link between reputation and responsibility. These authors suggest that there is a considerable similarity between the concepts of reputation and responsibility (e.g., in terms of how a business relates to me, how a business related to others and how a business relates to itself).

Therefore, the aim of this paper is to enhance our understanding of the relationship between sustainability and corporate image and reputation according to the legitimacy theory framework. We divide the concept of sustainability into three main dimensions: economic, social and environmental. To our knowledge, in no case has the influence of sustainability dimensions on the corporate image and reputation been studied simultaneously, which is a knowledge gap in the academic marketing literature. Consequently, this paper contributes to the existing literature in various ways. From a conceptual perspective, this work try to bridge a gap in the literature on the effects of sustainable issues on corporate image and reputation since previous studies do not consider both concepts (image and reputation) in relation to all sustainability dimensions (economy, society and environment) in a single model. From a methodological perspective, this research expands previous studies examining the effects of sustainability on corporate image and reputation by using personal surveys and not an experimental design (Keller and Aaker, 1998; Pfau et al., 2008).

Our findings show that the economic, social and environmental domains of sustainability have a direct and positive effect on both corporate image and reputation. Moreover, our results support the idea that efforts made by companies towards sustainability will be rewarded by the projection of a positive corporate image which will lead to increasing corporate reputation. This paper is structured as follows. The next section presents the theoretical framework and reviews the literature on corporate 
sustainability, image and reputation. The development of hypothesis is presented in section 2. Section 3 presents the research methodology followed by the presentation of the results. Finally, concluding remarks and implications for management are presented.

\section{Conceptual framework}

\subsection{Sustainability in business}

Academic literature defines the term sustainability in many different ways but over the years it has often been focused on environmental aspects. The argument in this paper follows a more comprehensive definition that is gaining worldwide prevalence. From a business point of view, sustainability connotes three dimensions: economic, social and environmental (Choi and $\mathrm{Ng}, 2011$; Sheth et al., 2011), which is also called the "Triple Bottom Line" (Elkington, 1998). In this research authors understand the notion of sustainability meaning "to meet the present needs without compromising the ability of future generations to meet their own needs" (WCED, 1987). Sustainability is an approach firms are increasingly adopting to conduct business. More than ever, companies not only have to focus on obtaining economic benefits but they must also seek to deliver environmental and social benefits (Elkington, 1998). However, results from several international studies show that this notion is being adopted slowly. According to a McKinsey Global Survey (2010), based on responses from nearly 2,000 executives, reports that despite its recognized importance, companies are not taking a proactive approach to managing sustainability. Additional results suggest that nowadays, companies are primarily concerned about issues in the area of environmental sustainability, and that most of the actions are compliance driven rather than strategic, and that they lack a long-term perspective (Hoffman and Woody, 2008). Therefore, it is necessary to understand the complexity of the concept of sustainability and its relationship with corporate image and reputation to further explain the creation of sustainable competitive advantages over time.

Sustainability is described as a threefold goal, including environmental, economic and social aspects. Among the three dimensions, environmental sustainability has received the most attention to date. This dimension refers to the maintenance of natural capital (Goodland, 1995). The "green" marketing concept literature studies environmental concerns within the discipline of marketing. The "green" marketing notion is expressed as green applications of a variety of established marketing topics including advertising 
and promotion, purchase intention, consumer behavior and marketing strategy (Choi and Ng, 2011). Academics and practitioners see "green" as a product option as part of the solution of sustainability and also as part of the problem since it still fosters consumption. As Stern (1997) argues, environmental damage caused by consumption threatens human welfare and health. The main environmental concerns arising from rapid growth in consumption are two-fold: environmental degradation risks and ecosystem resource constraints. Environmental risks are losses and harm such as biodiversity loss, deforestation and soil erosion due to climate change and pollution of water systems and land (Sheth et al., 2011). Eco-system constraints suggest that the earth cannot support unlimited growth in consumption (Speth, 2008). This orientation is limited when compared to more recent developments in the concern for the environment and to a broader orientation of sustainability having not only environmental aspects but also economic and social concerns (Choi and Ng, 2011; Sheth et al., 2011).

The economic dimension of sustainability refers to companies' ability to create value and enhance financial performance. With the enduring international economic and financial crisis, society is deeply concerned with economic sustainability due to fear of general job losses and financial risks to government and public programs (Choi and $\mathrm{Ng}$, 2011). Several authors have tried to articulate the significance of the economic dimension of sustainability. Sheth et al. (2011) have identified two different aspects of the economic dimension. The first one is related to conventional financial performance such as cost reductions, and the second issue relates to economic interests of external stakeholders such as a broad-based improvement in economic well-being and standard of living.

Finally, social dimension of sustainability describes the consideration of societal issues like tolerance toward others or equal rights (Goodland, 1995) and is concerned with the well-being of people and communities as a noneconomic form of wealth (Choi and $\mathrm{Ng}$, 2011). This dimension of sustainability has probably become more apparent due to the increasing number of financial scandals as well as a great number of public expectations of companies to do more for social well-being (Mohr and Webb, 2005). Business activities belonging to social and economic dimensions of sustainability have been considered reactive and opportunistic since social and economic initiatives typically take the form of discretionary programs or projects, falling under the common umbrella of CSR, which mostly tend not to be integrated with normal managerial responsibilities and standard business practices. 


\subsection{The importance of sustainability in creating a superior corporate reputation and legitimacy}

Publicly held worldwide organizations attempt to satisfy the demands of a variety of stakeholders in order to be allowed to operate in society (Miles and Covien, 2000). The commitment of the company to stakeholders is essential to develop the company's legitimacy through gaining and understanding stakeholders' expectations so they should focus on addressing economic, social and environmental expectations of these groups (Unerman and Bennet, 2004). By revealing sustainability initiatives, companies are able to facilitate the projection of a social image (Gray et al., 1995) which will lead to increased legitimacy and corporate reputation (Bebbignton et al., 2008; Fombrum et al., 2000; Pfau et al., 2008). Actually, the inclusion of social and environmental activities in the corporate agenda is a part of the conversation between organizations and their publics, and it provides information on firms' activities that help legitimize its behavior and educate, inform, and change perceptions and expectations of these stakeholders (Adams and Larrinaga, 2007; Keller and Aaker, 1998). Following Suchman (1995) legitimacy is "a generalized perception or assumption that actions of a firm are desirable, proper and appropriate within some socially constructed system of norms, values and beliefs". Both legitimacy and reputation represent assessments of an organization by a social system (Deephouse and Carter, 2005). These authors observe that there are several areas of overlap between both concepts. Since both notions represent social construction processes as stakeholders evaluate a company, these concepts are linked to the same antecedents such as size, financial performance or strategic posture, and they improve the ability to acquire resources. However, while legitimacy is conceived following Schuman's (1995) proposal, reputation is equated to image, prestige, esteem and goodwill, while developing the concept of corporate standing (Shenkar and Yuchtman-Yaar, 1997). With regard to this, corporate reputation can be conceptualized as the "set of perceptions held by people inside and outside a company" (Fombrun, 1996). A company's reputation is the perceptions of its relevant stakeholders, such as customers, employees, owners, suppliers and strategic partners, society and community (ranging from both local to international, including current and future generations), government or non-governmental organizations, among others. An advanced corporate reputation acts as both an intangible asset and a source of strategic 
advantage increasing companies' long term ability to create value (Caves and Porter, 1977) since corporate reputation is composed of a company's unique set of skills in delivering both economic and non-economic benefits (Fombrum, 1996). Sustainability is increasingly seen as a determinant of corporate reputation since firms show externally that they are aware of the need of managing a wider range of social and environmental issues (Friedman and Miles, 2001; Hillenbrand and Money, 2007). Furthermore, this concept is relied upon to enhance corporate reputation (Becker-Olsen et al., 2006; Pirsch et al., 2007) and academic literature has recently suggested that companies may use sustainability as a way to manage their reputation risk (Bebbington et al., 2008).

Sustainability has been found to reduce public scrutiny, providing a license to operate in society and enhancing the latitude of public tolerance when things go wrong (Klein and Dawar, 2004). In this way, sustainability may act as a barrier, permitting the company a certain degree of tolerance for error in what, through the responsibilities imposed by its reputation and the promises made in its marketing communications, audiences have come to expect (Pomering and Johnson, 2009). As previously mentioned, academics and practitioners attributed to corporate reputation built on sustainability aspects considerable power. General benefits attributed to sustainability include investment appeal, market share, business performance and organizational attractiveness, among others (Luce et al., 2001; Maignan et al., 1999). Firms that act in a socially responsible manner and have a history of fulfilling their obligations to various stakeholders are creating reputational advantage (Miles and Covin, 2000).

In the field of marketing, a concept that has led to some confusion regarding corporate reputation is the notion of corporate image. The term "corporate image" has been widely used in the marketing area and refers to the set of perceptions about the brand reflected as associations existing in the mind of the consumer (Keller, 1993; Keller and Aaker, 1998). In order to differentiate these two concepts, Gotsi and Wilson (2001) distinguished two different schools of thought regarding both concepts: 1) the analogous school of thought, which views corporate reputation as synonymous with corporate image, and 2) the differentiated school of thought, which considers the terms to be different and, according to the majority of the authors interrelated. This research is part of the differentiated school as it is the most contemporary view with the largest representation in the academic literature so that the corporate image is considered in this paper an antecedent of corporate reputation. 
The influence of sustainability on corporate image and reputation has been theoretically proposed but, as far as it is known, in no case has the influence of the dimensions of sustainability on any of these variables been analyzed. The importance of knowing if such influence exists in practice and determining its magnitude is due to the fact that this effect would provide empirical support for the idea that sustainability is an important source of competitive advantage (Caves and Porter, 1977; Fombrun, 1996) generating multiple business benefits. Hence, and based on the previous literature review we propose:

$\mathbf{H}_{1}$ : The economic dimension of sustainability has a positive direct effect on corporate image.

H2: The social dimension of sustainability has a positive direct effect on corporate image.

H3: The environmental dimension of sustainability has a positive direct effect on corporate image.

$\mathbf{H}_{4}$ : The economic dimension of sustainability has a positive direct effect on corporate reputation.

H5: The social dimension of sustainability has a positive direct effect on corporate reputation.

H6: The environmental dimension of sustainability has a positive direct effect on corporate reputation.

$\mathbf{H}_{7}$ : Corporate image has a positive direct effect on corporate reputation.

Please, insert FIGURE 1 here

\section{Methodology}

\subsection{Data collection and sample}

In order to test the hypotheses, personal surveys of hotel customers were conducted in Spain according to a structured questionnaire. To design the research sample, a nonprobability sampling procedure was chosen (Trespalacios et al., 2005). Specifically, a convenience sample was used. Therefore, to ensure greater representation of the data, a multistage sampling by quotas was made by characterizing the population according to two criteria relevant to the investigation: the sex and the age of the respondent. From 
the target sample of 400 questionnaires, 382 questionnaires were completed, 18 were discarded as incomplete. Hence, the final response rate was $95.5 \%$. Data were gathered during the month of April 2011 in the Autonomous Community of Cantabria (Spain). The final sample consists of 186 females (49\%) and 196 males (51\%); 38 under the age of 25 (10\%); 74 between the ages of 25 and 34 (19.5\%); 71 between the ages of 35 and 44 (18.5\%); 76 between the ages of 45 and 54 (20\%) and 123 over the age of 55 (32.1\%). Finally, we decided to conduct our research in the Spanish tourism industry, more specifically in the hospitality sector, for several reasons. First, it is a sector in which socially responsible initiatives are developed and secondly, this research field helps us avoid the limitations of laboratory experiments, since data are obtained in real conditions of use. Table 1 displays the main characteristics of the research.

\section{Please, insert TABLE 1 here}

\subsection{Measures}

Preliminary versions of the questionnaire were administered to a convenience sample of 18 consumers, and pretest results were used to improve measures and design and appropriate structure for the questionnaire. Existing well-established multiple-item 7point Likert scales were adopted to measure our variables. Sustainability dimensions were measured using a seventeen-item scale from Martínez et al. (2013). Corporate image was measured using a seven-item scale from Carrasco et al. (2008). Finally we measured corporate reputation with four items developed by Ahearne et al. (2005). The final measures are provided in the Appendix.

\subsection{Psychometric properties of the measurement instrument}

In order to accomplish the objectives of our research, the authors followed Anderson and Gerbing's (1988) two-stage procedure. First of all, the goodness of the measurement instrument's psychometric properties was analyzed by Confirmatory Factor Analysis (CFA) and secondly, the structural relations among the theoretically proposed latent variables were analyzed through a Structural Equation Model (SEM). Both the measurement model and the causal relations model were estimated using the Maximum Likelihood Method with robust estimators using EQS v.6. The psychometric properties (reliability and validity) of the measurement instruments were assessed by a 
confirmatory factor analysis containing all the multi-item constructs in our theoretical framework by using EQS v.6 (Bentler, 1995). The reliability of the measurement scales proposed was evaluated using the Cronbach's alpha coefficient and by an Average Variance Extracted (AVE) (Hair et al., 2010) (Table 2). The values of these statistics exceed the minimum recommended values of 0.7 and 0.5 , respectively (Hair et al., 2010), which confirm the internal reliability of the model. In addition, all the items are significant at a confident level of $95 \%$ and their standardized lambda coefficients exceed 0.5 (Steemkamp and Van Trijp, 1991), confirming the convergent validity of the model (Table 2). Finally, in order to confirm the discriminant validity, we followed the procedure described by Fornell and Larcker (1981) who compare the correlations of the factors with the square root of the average variance extracted for each of the factors. Discriminant validity can be established if the square root of the average variance extracted for each one of the factor is greater that the correlations among the factors. Although the correlation between the economic and social dimension is marginally superior than the square root of the average variance extracted for the social dimension, results presented in Table 3 provide evidence for discriminant validity. Therefore, the measurement model proposed is correct. Finally, the goodness of fit of the analysis was verified with the Satorra-Bentler $\chi 2(\mathrm{~S}-\mathrm{B} \chi 2)(\mathrm{p}<0.05)$ and the comparative fit indices NFI, NNFI, IFC and IFI, which are the most common measures for confirmatory tests (Uriel and Aldás, 2005). All values were greater than 0.9 (Bentler, 1995), indicating that the model provides a good fit. Table 2 shows the statistics calculated to verify these properties and the main goodness of fit indicators.

Please, insert TABLE 2 here

Please, insert TABLE 3 here

\section{Analysis of structural relations and hypothesis testing}

Table 4 shows the standardized coefficients for the structural relations tested. As can be seen, the goodness of fit indices for the structural model show a good fit and therefore it is feasible to test the proposed hypotheses. $\mathrm{H} 1, \mathrm{H} 2$ and $\mathrm{H} 3$ are supported $\left(\beta=0.388^{*}\right.$; $\beta=0.259 * ; \beta=0.207 *$ ) as the economic, social and environmental dimension of sustainability have a positive direct effect on corporate image. H4, H5 and H6 are 
confirmed $\left(\beta=0.328^{*} ; \beta=0.237^{*} ; \beta=0.184^{*}\right)$ as the economic, social and environmental domain of sustainability has a positive direct effect on corporate reputation. These results give empirical support to the idea that the efforts made by companies towards sustainability will be rewarded by the projection of a positive corporate image which will lead to increasing corporate reputation. Finally, H7 expects that corporate image will have a positive effect on corporate reputation. H7 $\left(\beta=0.654^{*}\right)$ is supported. Therefore, the proposed model is totally supported by the results.

Please, insert TABLE 4 here

Please, insert FIGURE 2 here

\subsection{Testing for mediation}

To test the mediation effect of corporate image hypothesized as linking the independent variables (economic, social and environmental sustainability) and dependent variable (corporate reputation), four alternative structural models were estimated following the test procedures proposed by Baron and Kenny (1986) ${ }^{2}$. Prior to the examination of a mediating effect, analysis of the four conditions under which the existence of mediation can be supported is crucial.

The first condition is satisfied if the independent variables (economic, social and environmental sustainability) directly influence the mediators (image). The second condition is met if the mediator (image) directly influences the dependent variable (reputation). The results of Model 1 and Model 2 (Table 5) indicate that both conditions have been satisfied. The third condition suggests that the independent variables (economic, social and environmental sustainability) must significantly influence the dependent variable (reputation). This condition was investigated in a model with a direct path from the independent variables to the dependent variable, without the presence of mediators (Model 2). As Table 5 indicates, the path was significant $(\mathrm{p}<0.05)$, therefore satisfying this condition. The fourth condition is met if, after including the paths from the independent variable to the mediator, the direct paths from the independent variable (sustainability dimensions) to the dependent variable (reputation) become non significant (full mediation) or reduce their strength (partial mediation). Using the results presented in Table 5, a comparison of Model 3 and Model 4 indicates that, after the inclusion of the mediator (image), the direct path from the 
independent variables (sustainability dimensions) to the dependent variable (reputation) reduces their strength, thus satisfying the fourth condition. According to Baron and Kenny (1986) our findings show a "partial mediation" since our model presents indirect and direct effects between corporate image and reputation. However, recent studies exploring the criteria for establishing mediation consider that direct paths often result from omission of one or more mediators from the model (Shrout and Bolger, 2002; Zhao et al., 2010). In the next section we propose future lines of research in order to overcome this limitation. Another explanation for this direct effect is due to measurement error in the indicator of the mediator variable (for further information see Birnbaum and Mellers, 1970).

Please, insert TABLE 5 here

\section{Conclusions, limitations and future lines of research}

Following the theoretical debate on the importance of sustainability when developing a superior corporate reputation, this study empirically investigates whether there is a relationship between sustainability (conceptualized as a multidimensional construct) and corporate image and reputation. The authors conducted a survey to test the hypotheses and design a structural equation model to analyze them. The first three hypotheses suggest that the economic, social and environmental domains of sustainability are effective in influencing corporate image. Similarly, hypotheses four to six propose that the economic, social and environmental dimensions of sustainability present a positive and direct relationship with corporate reputation. Finally, following the principles of the differentiated school of thought (Gotsi and Willson, 2001) it is proposed that corporate image contribute to more positive perceptions of corporate reputation. Our empirical evidence supports all the proposed hypotheses. Moreover, this study demonstrates that the effect of sustainability dimensions on corporate reputation is mediated by corporate image.

Such findings are relevant since they add several contributions to the existing marketing literature. First of all, they provide empirical evidence of sustainability factors influencing corporate image and reputation. Since previous works have essentially focused on the role of CSR, this study adds to our understanding of the relationship between the three domains of sustainability and corporate image and reputation. This confirms that sustainability plays a vital role as an antecedent variable of both corporate 
image and reputation. In this sense, it seems that the economic and social dimensions of sustainability present the greatest influence on both intangible assets. Thus, companies must reveal information to their stakeholders regarding economic and social issues (e.g., obtain the greatest possible profits, achieve long-term success, improve its economic performance, ensure their survival and success in the long run, help to solve social problems, play a role in society that goes beyond mere profit generation, collaborate in cultural and social events, improve the welfare of local communities ...). This way, by providing relevant information to stakeholders about the firm regarding sustainability, companies will obtain a competitive advantage based on a good image and reputation. Second, we show that the principles of the differentiated school of thought regarding the relationship between corporate image and reputation are met in this research supporting recent studies.

The present study has a number of implications for marketing practitioners. The most important implication for practitioners is that the economic, social and environmental dimensions of sustainability present a direct and positive relationship with both corporate image and reputation. This should give managers the argument they need to justify the costs that are associated with sustainable issues. Environmental aspects have, in the past, been primarily important to companies. However, nowadays firms must become much more interested in the marketing implications of their corporate sustainability policy and actions, including economic and social issues, since this research demonstrates the positive effect of these aspects on both corporate image and reputation. Additionally, these findings suggest that the areas of corporate image, reputation and sustainability are strongly interrelated, so it follows that these concepts could be managed in an integrated way. Companies are encouraged to explore how corporate sustainability and reputation activities could positively be managed jointly, since organizations may manage these concepts in separate business areas. Finally, by involving stakeholders in defining the sustainable activities of the company, it would be possible to add legitimacy of how the notion of sustainability can de defined, measure and implemented within the firm.

Finally, to refine the findings of this study, some limitations of this work are outlined below. The present research focuses on the concepts of corporate image, reputation and sustainability. Our findings suggest that sustainability should not be taken to be generalizable to other concepts such as CSR. While the results suggest that economic, social and environmental aspects are key components to sustainability, richer and in- 
depth views of this concept are needed since, as recent academics state, there is a lack of work focusing on the consumer's perspective regarding sustainable aspects (Sheth et al., 2011). Besides, the significant direct effect between corporate image and reputation points to the possible existence of some omitted mediator that can be pursued in future research (Zhao et al., 2010). Researchers are encouraged to look for alternative mediators. With regard to this, Davies and Miles (1998) propose corporate identity as a key element of corporate reputation. So by including this new variable in our model, futures studies would contribute to a superior explanatory power and to a better understanding of the nature of corporate reputation. Moreover, the current study has been conducted with consumers of hotel companies in Spain and it is not clear in how far the findings can be generalized to other industries, stakeholders or countries. Future research could extend this research by including different stakeholders' expectations of corporate sustainability, image and reputation. Therefore, it would be interesting to replicate this studio but considering various stakeholders to ensure that our results are extrapolated to all target groups (employees, investors, suppliers ...).

\section{NOTES}

${ }^{1}$ Sustainability research has not become a widely studied topic in premier marketing journals mainly because previous research has considered the term of "sustainability" as a synonymous of other notions such as "corporate social responsibility" (CSR) (Dahlsrud, 2008; Montiel, 2008; van Marrewijk, 2003). This lack of consensus has lead to a critical situation that has put business executives in an awkward situation and academics in great confusion and ambiguity. From a conceptual point of view, corporate sustainability is the "ultimate goal" of organizations, meeting the needs of the present without compromising the ability of future generations to meet their own needs (WCED, 1987), whereas CSR is an intermediate stage where companies try to balance the triple-bottom line (van Marrewijk, 2003). Linnanen and Panapanaan (2002) consider that the three aspects of sustainability (economic, environmental and social) can be translated into a CSR approach that companies have to be concerned with.

Consistent with this line of though, several academics state that the conceptualization of CSR that integrates economic, social and environmental dimensions and the triplebottom line conceptualization of sustainability, which comprises economic, social and environmental dimensions are very similar (Linnanen and Panapanaan, 2002; Montiel, 2008; van Marrewijk, 2003). Both approaches show that firms must balance the three 
elements of the triple-bottom line to achieve long-term sustainability and social responsibility.

Much of the confusion between the two terms comes from the fact that historically, sustainability related to the environment while CSR referred to social aspects (Montiel, 2008). Actually, considerable efforts have been made to study the social dimension of sustainability in the CSR context (Choi and $\mathrm{Ng}$, 2011). In this sense, CSR is one of the most prevalent topics concerning the social dimension studied in sustainability research (Lichtenstein et al., 2004). This vision is particularly interesting when one considers how the term CSR is sometimes used in a very narrow sense to represent charitable donations, community involvement and employee voluntarism (Hillenbrand and Money, 2007).

In order to differentiate between both constructs Montiel (2008) argue that the main difference between these concepts relates to their conceptualization of the economic dimension. Sustainability scholars tend to argue that the economic, social, and environmental pillars are interconnected (Choi and $\mathrm{Ng}$, 2011; Sheth et al., 2011). Actually, sustainability describes a nested system that recognizes that the economy is part of society, which in turn is part of the larger ecological system (Bansal, 2005). However, most empirical CSR research treats social and economic performance as independent components (Montiel, 2008). In CSR literature social responsibility "supplements" the primary fundamental responsibility of businesses: economic prosperity (Carroll, 1979). However, in the sustainability case, social, environmental and economic responsibilities are "complementary". Consequently, the three elements must be integrated to achieve perfection (sustainability) (Bansal, 2005).

In the present study, sustainability is considered as a broader concept than CSR that understand the economic, social and environmental dimensions as dependent components and not as isolated factors.

${ }^{2}$ Researchers tend to follow the causal steps approach outlined by Baron and Kenny (1986) and rely upon the significance test of the relationship between the independent and dependent variable to assess whether there is a significant total effect and thus decide whether it is appropriate to proceed with examining indirect effects, and assess the extent, and therefore the importance or completeness, of any mediation observed (Rucker et al., 2011). The authors of this paper have based their analysis on Baron and Kenny's (1986) research due to its academic relevance (Baron and Kenny's article had 
been cited by 21,637 journal articles as of October 2013, according to Social Sciences Citation Index). However, recent studies have revised the guidelines provided by Baron and Kenny (1986) about mediation analysis (Shrout and Bolger 2002; Zhao et al., 2010; Rucker et al., 2011) highlighting that there need not be a significant effect of the independent variable on the dependent variable to establish mediation. For instance, Zhao et al. (2010) recommend that to establish mediation the Baron-Kenny causal steps approach should be replaced with one and only one test: the bootstrap test of the indirect effect $\mathrm{a} \times \mathrm{b}$. The authors have included this footnote in order to introduce new methodological approaches to potential readers and to encourage future studies to carry out additional tests to verify mediation analysis.

\section{Acknowledgements}

This research was funded by the FPU Scholarship Program provided by the Spanish Ministry of Education, Culture and Sports. The authors would like to thank the editor and reviewers for their insightful and constructive comments.

\section{References}

Adams, C.A. and Larrinaga-González, C. (2007) "Engaging with organizations in pursuit of improved sustainability accounting performance". Accounting, Auditing and Accountability Journal, 20(3), 333-355.

Ahearne, M., Jelinek, R. and Rapp, A. (2005) "Moving beyond the direct effect of SFA adoption on salesperson performance: Training and support as key moderating factors". Industrial Marketing Management, 34(4): 379-388.

Anderson, J. C. and Gerbing, D. W. (1998) "Structural equation modelling in practice: A review and recommended two-step approach". Psychological Bulletin, 103(3): 411423.

Bansal, P. (2005) "Evolving sustainably: A longitudinal study of corporate sustainable development". Strategic Management Journal, 26(3): 197-218.

Baron, R.M. and Kenny, D.K. (1986) "Moderator-mediator variables distinction in social psychological research: Conceptual, strategic, and statistical considerations". Journal of Personality and Social Psychology, 51(6): 1173-1182.

Bebbignton, J., Larrinaga-González, C. and Moneva, J.M. (2008) "Corporate social responsibility and reputation risk management". Accounting, Auditing and Accountability Journal, 21(3): 337-362. 
Becker-Olsen K. L.; Cudmore B. A. y Hill R. P. (2006) "The impact of perceived corporate social responsibility on consumer behavior". Journal of Business Research, 59(1): 46-53.

Bentler, P. M. (1995) EQS structural equations program manual. Multivariate Software Encino, CA.

Birnbaum, Michael H. and Barbara A. Mellers (1979) "Stimulus recognition may mediate exposure effects". Journal of Personality and Social Psychology, 37(3): 391394.

Carrasco, I.B., Salinas, E.M. and Pérez, J. (2008) "Extensiones de marca en bienes y servicios: Evaluación y efectos sobre la imagen de marca". Revista Española de Investigación de Marketing ESIC, 12(2): 25-43.

Carroll, A.B. (1979) "A three-dimensional conceptual model of corporate performance". Academy of Management Review, 4(4):497-505.

Caves, R.E. and Porter, M.E. (2007) "From entry barriers to mobility barriers: Conjectural decisions and contrived deterrence to new competition". Quarterly] ournal of Economics, 91: 241-262.

Choi, S. and Ng, A. (2011) "Environmental and economic dimensions of sustainability and price effects on consumer responses". Journal of Business Ethics, 104: 269-282.

Dahlsrud, A. (2008) "How corporate social responsibility is defined: An analysis of 37 definitions". Corporate Reputation Review, 15: 1-13.

Davies, G. and Miles, L. (1998) "Reputation management: Theory versus practice". Corporate Reputation Review, 2(1): 16-27.

Deephouse, D.L. and Carter, S.M. (2005) "An examination of differences between organizational legitimacy and organizational reputation". Journal of Management Studies, 42(2): 329-360.

Elkington, J. (1998) Cannibals with forks: The triple bottom line of the 21st century business. Capstone Publishing, Ltd. Oxford.

Fombrun, C.J. (1996) Reputation: Realizing value from the corporate image. Harvard Business School Press.

Fombrun, C.J., Gardberg, N.A. and Barnett, M.L. (2000) "Opportunity platforms and safety nets: Corporate citizenship and reputational risk". Business and Society Review, 105(1): 85-106.

Fombrun, C.J. (2005) "Building corporate reputation through CSR initiatives: Evolving standards". Corporate Reputation Review, 8(1): 7-11. 
Fornell, C. and Larcker, D.F. (1981) "Evaluating structural equation models with unobservable variables and measurement error", Journal of Marketing Research, 28: $39-50$.

Friedman, A.L. and Miles, S. (2001) "Socially responsible investment in corporate social and environmental reporting in the UK: An exploratory study", British Accounting Review, 33(4): 523-548.

Goodland, R (1995) “The concept of environmental sustainability". Review of Ecology Systems, 26: 1-24.

Gotsi, M. and Wilson, A. (2001) "Corporate reputation management: Living the brand", Management Decision, 39(2): 99-116.

Hair, J.F., Black, W.C., Babin, B.J. and Anderson, R.E. (2010) Multivariate Data Analysis. Pearson Prentice-Hall, Upper Saddle River, NJ.

Hillenbrand, C. and Money, K. (2007) "Corporate social responsibility and corporate reputation: Two separate concepts or two sides of the same coin?". Corporate Reputation Review, 10: 261-277.

Hoffman, A.J. and Woody, J.G. (2008) Climate Change? What's Your Business Strategy?. Harvard Business School Press, Boston, MA.

Keller, K.L. (1993) "Conceptualizing, measuring, and managing customer-based brand equity". Journal of Marketing, 57(1): 1-22.

Keller, K.L. and Aaker, D.A. (1998) "The impact of corporate marketing on a company's brand extensions". Corporate Reputation Review, 1(1): 356-378.

Klein, J. and Dawar, N. (2004) "Corporate social responsibility and consumers' attributions". International Journal of Research in Marketing, 21: 203-217.

Lichtenstein, D.R., Drumwright, M.E. and Braig, B.M. (2004) "The effect of corporate social responsibility on customer donations to corporate-supported nonprofits." Journal of Marketing, 68: 16-33.

Linnanen, L. and Panapanaan, V.M. (2002) "Roadmapping CSR in Finnish companies". Helsinki: Helsinki University of Technology.

Lubin, D. A. and Esty, D. C. (2010) "The Sustainability Imperative”. Harvard Business Review, 88(5): 42-50.

Luce, R. A., Barber, A. E. and Hillman, A. J. (2001) "Good deeds and misdeeds: A mediated model of the effect of corporate social performance on organizational attractiveness". Business Society, 40(4): 397-415.

Maignan, I., Ferrell, O. C. and Hult, G. T. M. (1999) “Corporate citizenship: Cultural 
antecedents and business benefits". Journal of the Academy of Marketing Science, 27(4): 455-469.

Martínez, P., Pérez, A. and Rodríguez del Bosque, I. (2013) "Measuring corporate social responsibility in tourism: Development and validation of an efficient measurement scale in the hospitality industry". Journal of Travel \& Tourism Marketing, 30: 365-385.

Miles, M.P. and Covin, J.G. (2000) "Environmental marketing: A source of reputational, competitive, and financial advantage". Journal of Business Ethics, 23(3): 299-311.

Mohr, L.A. and Webb, D.J. (2005) "The effects of corporate social responsibility and price on consumer responses". The Journal of Consumer Affairs, 39(1): 121-147.

Montiel, I. (2008) "Corporate social responsibility and corporate sustainability separate pasts, common futures". Organization \& Environment, 21(3): 245-269.

Pfau, M., Haigh, M.M., Sims, J. and Wigley, S. (2008) "The influence of corporate social responsibility campaigns on public opinion". Corporate reputation Review, 11: $145-154$.

Pirsch, J., Gupta, S. and Grau, S. L. (2007) “A framework for understanding corporate social responsibility programs as a continuum: An exploratory study". Journal of Business Ethics, 70(2): 125-140.

Pomering, A. and Johnson, L. (2009) "Constructing a corporate social responsibility reputation using corporate image advertising". Australasian Marketing Journal, 17(2): 106-114.

Rucker, D.D., Preacher, K.J., Tormala, Z.L. and Petty, R.E. (2011) "Mediation analysis in social psychology: Current practices and new recommendations". Social and Personality Psychology Compass, 5(6): 359-371.

Shenkar, O. and Yuchtman-Yaar, E. (1997) "Reputation, image, prestige and goodwill: An interdisciplinary approach to organizational standing". Human Relations, 50(11): 1361-1381.

Sheth, J.N., Sethia, N.K. and Srinivas, S. (2011) "Mindful consumption: A customercentric approach to sustainability". Journal of the Academy Marketing Science, 39(1): 21-39.

Shrout, P.E. and Bolger, N. (2002) "Mediation in experimental and nonexperimental studies: New procedures and recommendation". Psychological Methods, 7(4): 422-445. 
Speth, J.G. (2008) The bridge at the edge of the world. New Haven, Yale University Press.

Steenkamp, J. B. and van Trijp, H. C. M. (1991) "The use of LISREL in validating marketing constructs”. International Journal of Research in Marketing, 8(4): 283-299. Stern, D.A. (1997) “The capital theory approach to sustainability: A critical appraisal”. Journal of Economic Issues, 31(1): 145-173.

Suchman, M.C. (1995) "Managing legitimacy: Strategic and institutional approaches". Academy of Management Journal, Vol. 20, No. 3, 571- 610.

Trespalacios, J. A., Vázquez, R. and Bello, L. (2005) Investigación de Mercados. Thomson, Madrid.

Unerman, J. and Bennett, M. (2004) "Increased stakeholders dialogue and the Internet: Towards greater corporate accountability or reinforcing capitalist hegemony?". Accounting Organizations and Society, 29(7): 685-707.

Uriel, E. and Aldás, J. (2005) Análisis multivariado aplicado, Thomson, Madrid. van Marrewijk, M. (2003) "Concepts and definitions of CSR and corporate sustainability: Between agency and communion”. Journal of Business Ethics, 44(2), 95105.

World Commission on Environment and Development (1987) From One Earth to One World: An Overview, Oxford: Oxford University Press.

Zhao, X., Lynch, J. G., Jr. and Chen, Q. (2010) Reconsidering Baron and Kenny: Myths and truths about mediation analysis. Journal of Consumer Research, 37, 197-206. 